\title{
Analysis of Factors Influencing Impulse Buying Behavior towards e-Tailing Sites
}

\author{
Md Wasiul Karim* \\ Department of Business Administration, International Islamic University Malaysia \\ E-Mail:wasiul45@gmail.com \\ Mohammad Abdul Matin Chowdhury \\ Department of Finance, International Islamic University Malaysia \\ E-Mail: matinchy@outlook.com \\ Md Abdullah Al Masud \\ Department of Business Administration, International Islamic University Malaysia \\ E-Mail: rony.masud1986@gmail.com \\ Md. Arifuzzaman \\ Graduate School of Management, International Islamic University Malaysia \\ E-Mail: shemon03@gmail.com
}

\begin{abstract}
Impulse buying behavior among consumers was previously examined within the brick-and-mortar stores. The internet revolution is the shift from a traditional retail environment to electronic commerce where products and services are offered online and consumers benefit from buying impulse towards e-tailing sites. By applying the S-O-R model, this study seeks to evidently identify the influencing factors of impulse buying behavior towards e-tailing sites. The survey data were analyzed using partial least squares structural equation modeling (PLS-SEM). The result indicates that website stimulus has no significant positive relationship with online impulsive buying behavior, but an indirect relationship is found to be associated with impulse buying behavior. Results also highlighted that website stimulus, marketing stimulus, and product variety positively influence perceived enjoyment, where perceived enjoyment was a strong predictor of online impulse buying behavior. The study contributes to the existing literature by
\end{abstract}


employing external stimuli of the research framework. It was thus recommended to the online e-tailers to maximize their relationship with consumers by providing valuable products and services through online platforms.

Keywords: Impulse buying behavior, e-Tailer, Consumer behavior, Internet marketing, SO-R framework, PLS-SEM, Malaysia

\section{INTRODUCTION}

Following the rising number of consumers who prefer to buy impulsively from etailing sites, academic research focuses on online impulse buying as a research topic. To date, most studies on this trend have examined how online store elements represented and experienced by consumers influence buying impulses and thus offer retailers insight into how online store buying impulses can be stimulated (Park et al., 2012). E-commerce sites in today's era played a significant role by providing vast opportunities for companies to interact with their clients on a real-time basis (Arbaina \& Suresh, 2018). It is therefore incumbent on companies to foresee a plan to make their presence known on e-tailing sites. Although some companies have begun reorganizing advertising strategies, it is important that their pages are readily accessible to consumers to be competitive.

Impulse buying is described as the unplanned, sudden, and spontaneous buying behavior of the consumers. Li (2015) also described impulsive behavior as unintentional, unreflective buying due to physical proximity and emotional intimacy to the desired product, resulting in personal gratification. However, the internet has diverted consumers' attention towards online shopping sites worldwide (Floh \& Madlberger, 2013). According to $\mathrm{Wu}$ et al. (2016), roughly eighty percent of consumer retail purchases are impulsive. That could be a reason why retailers and vendors are targeting impulsive buyers in view of its importance. The online buying phenomenon is becoming popular worldwide with the emerging field of e-commerce. Research shows that users online are more impulsive than those offline (Mwencha et al., 2014). There is an array of information about e-commerce sites. If the service delivery does not follow a reasonable standard, the sites and companies will quickly lose their reputation. A structured web presence with a defined workforce helps create customer relationships and helps to effectively introduce the brand to potential customers (Arbaina \& Suresh, 2018).

In the process of online transactions, buyers first gather information about the items they wish to buy, then place the order and make the payment before delivery (Hashmi et al., 2019). In some cases, trust and the quality of the websites are found to be attractive 
among consumers (Floh \& Madlberger, 2013; Wu et al., 2016). In addition to the factors which refer to the external and internal environment of markets, promotions, and discounts, also influence buying impulse behavior. It thus results in brand loyalty and a successful relationship (Al-Salamin \& Al-Hassan, 2016). It has been claimed that prolonged sales and promotions have a negative impact on the product's brand image and can lead to organizational losses (Al-Salamin \& Al-Hassan, 2016).

Muruganantham and Bhakat (2013) developed an impulse buying behavior framework by employing external and internal stimuli additionally, situational and demographic factors and suggested those factors to be employed in the future study. However, Muruganantham and Bhakat (2013) highlighted external stimuli as the most challenging factors, especially in the field of marketing stimuli and store-related factors. In terms of an online impulse purchase, consumers' confidence in the e-commerce platform is crucial because several risks are associated with transactions online. It is, therefore, an important element to be analyzed. It is further suggested by Muruganantham and Bhakat (2013) that retailers should exploit external stimuli by formulating effective marketing strategies to reach the potential buyers within the store.

Website stimuli have been widely studied in Malaysia in the context of online buying behavior (Hasanov \& Khalid, 2015; Lee et al., 2016). However, impulse buying behavior was not critically reviewed or investigated in previous studies in a Malaysian context. Furthermore, less attention has been paid to the variety-seeking behavior among consumers who like to buy impulsively online in Malaysia. It is against this background that it is deemed necessary to investigate variety-seeking behavior in the case of online impulse buying. The current study aims to fill this research gap by investigating the factors which mostly influence consumers to indulge in impulsive shopping from e-tailing stores.

\section{LITERATURE REVIEW}

\section{Stimulus Organism Response Model}

The Stimulus Organism and Response Model (S-O-R) introduced by Mehrabian and Russell (1974) are widely applied as a theoretical foundation for studies relevant to consumers' behavior (Zhu et al., 2015). Stimuli, in the SOR model, are believed to have an impact on individuals' internal state (Eroglu et al., 2001). An organism is defined as an internal process or condition which mediates the relationship between the stimulus and the final response of the person. The response is the ultimate outcome that determines consumer behavior or avoidance (Mehrabian \& Russell, 1974). According to the S-O-R 
model, consumers' feelings become an imperative part of responding to the revealing environmental stimulus (Hetharie et al., 2019). These feelings are also influenced by sensible and insensible perceptions and environmental understandings (Donovan \& Rossiter, 1982). So, several factors relevant to products/items' characteristics can be included in the S-O-R model of consumer behavior, for example, price, promotions, branding, and quality (Buckley, 1991).

Price and quality both carry some influence on consumers' choices (Monroe \& Bitta, 1978). The reduction in the price of a sovereign brand is considered as good value for the spending while consumers considered the sovereign brand for the quality (Buckley, 1991), lowering the price for a brand is considered as resetting the fair price, not as a promoting quality at a lower price (Bemmaor, 1984). The promotions such as coupons, special price reductions, advertisements, and in-store displays influence consumers' behavior (Chevalier, 1975).

Moreover, convenient locations, merchandize quality, price levels, variety of choices, service, atmosphere, adequate advertisements, and salespersons have a different impact on consumer behavior (Buckley, 1991).

Donovan and Rossiter (1982) applied the SOR model in the context of consumer behavior for the first time. Latter, Peng and Kim (2014) applied the SOR model to investigate the online shopping behavior of consumers and found that the web environment plays an important role in online buying. Shen and Khalifa (2012) studied online impulse purchases by employing the SOR model, and results revealed the importance of website design as stimuli to predict unplanned purchases online. Liao et al. (2016) explained the role of the SOR model and examined product type and online store display as one of the key determinants and stimuli of emotions that trigger consumers' desire to buy impulsively. Sultan et al. (2018) define impulse buying behavior by implementing the SOR model where window display, promotional activities, and store atmosphere were key triggers for determining a consumer's impulsive nature through positive emotion.

However, many researchers (Ahmad et al., 2019; Bharathi \& Sudha, 2017; Graa \& Dani, 2012; Hashmi et al., 2019) have studied consumers' stimuli, emotional responses, and impulse purchase by adapting the SOR model.

\section{Impulse Buying Behavior}

Impulse buying behavior is an instant and swift purchase deprived off of any preceding intention to shop towards an exact product type to meet certain needs (Beatty \& Ferrell, 1998). Such behavior occurs after customers experience a swift incidence of a very 
sturdy urge to buy and are obligated to make an impulsive purchase without adequate contemplation (Hausman, 2000). The motive to make impulsive buying is a multifaceted hedonic aspect that frequently stimulates emotive conflict, which could be impending from psychological and emotional (internal) or from the influence of marketers (external) (Rook \& Fisher, 1995). Piron (1991) conducted an in-depth analysis of the impulse purchasing literature, introduced a more precise and detailed impulse purchasing concept that includes four components: unplanned, the result of exposure to a stimulus, on-the-spot decision, and involvement of emotion. Previous research has categorized buying impulses into four types: pure, suggestion reminded, and planned (Stern, 1962). A pure impulse purchase is when a purchase is made suddenly without any calculations and thoughts. This category is predominantly reliant on emotions. Suggestion impulse purchase refers to a person who is motivated by self-suggestion to try out new products because the customer has no prior knowledge of the products. Thus, he/she wants to try something new. A reminded impulse purchase is when customers notice the products they have seen before, which triggers them to purchase. Planned impulse purchases occur when shoppers are preparing to buy but do not precisely know the particular items they wish to purchase.

Most popular impulse buying research has previously concentrated on brick-andmortar stores (Bhuvaneswari \& Krishnan, 2015; Choudhary, 2014; Jones et al., 2003; Karbasivar \& Yarahmadi, 2011; Verplanken \& Herabadi, 2001). Due to the revolution of web 2.0, traditional brick-and-mortar stores have experienced a great demise and have seen many companies transition to online platforms. Currently, many researchers have conducted research to examine consumers' impulse buying behavior online, where virtual atmosphere plays a crucial role in attracting consumers (Akram et al., 2018), additionally price, discounts, and bonuses (Park et al., 2012; Xu \& Huang, 2014).

\section{Impulse Buying Behavior vs. Unplanned Buying Behavior}

A significant and critical type of shopping behavior has been considered unplanned or impulse purchasing, but today researchers continue to discover numerous aspects and predictors that trigger unplanned purchasing. Impulse buying was described by Engel and Blackwell (1982) as a buying activity carried out when the need to purchase was not previously recognized, nor was a purchasing intention established prior to entering the shop.

Another description provided by (Beatty \& Ferrell, 1998) claimed that in a retail sense, impulse buying was a sudden and spontaneous purchase without pre-shopping intentions either to purchase the particular product category or to fulfill a particular 
purchasing task. Unplanned or intentional purchasing is an important part of contemporary shopping habits, and hedonic gratification is closely associated with the purchase of impulses. When customers are unexpectedly stimulated by the shopping experience and buy goods or services impulsively, unplanned purchases occur (Lu \& Wu, 2019). The study of (Liu et al., 2013) also demonstrates that unplanned buying and impulse buying are the same in nature as in both occurrences, the buying behavior occurs without prior planning and thinking.

Table1 Impulsive Buying between Offline and Online Retailing Environments

\begin{tabular}{|l|l|l|}
\hline $\begin{array}{c}\text { Impulse } \\
\text { Buying } \\
\text { Behavior }\end{array}$ & \multicolumn{1}{|c|}{ Offline } & \multicolumn{1}{c|}{ Online } \\
\hline Environment & $\begin{array}{l}\text { Buying impulse often occurs } \\
\text { based on an encounter of } \\
\text { certain stimuli, such as layout } \\
\text { design, lighting, music, and } \\
\text { product assortments (Summers } \\
\text { \& Hebert, 2001) }\end{array}$ & $\begin{array}{l}\text { Buying impulse occurs when } \\
\text { discounts and promotions are given } \\
\text { online. Visual appeal such as } \\
\text { website design and color also } \\
\text { attracts consumers (Akram et al., } \\
\text { 2018). }\end{array}$ \\
\hline Types & $\begin{array}{l}\text { Traditional "brick-and-mortar" } \\
\text { stores where consumers look } \\
\text { around and ask if they have } \\
\text { any questions and if consumers } \\
\text { are satisfied with an answer } \\
\text { they end up purchasing that } \\
\text { product (Bhuvaneswari \& } \\
\text { Krishnan, A review of } \\
\text { literature on impulse buying } \\
\text { behaviour of consumers in } \\
\text { online platforms where price, } \\
\text { promotions and payment methods } \\
\text { arick \& mortar and click only } \\
\text { et al., 2017). }\end{array}$ \\
\hline Stores, 2015)
\end{tabular}




\section{Perceived Enjoyment}

Enjoyment refers to an individuals' emotional state wherever it plays an important role in buying behavior. A perceived enjoyment can be described as the pleasure that a consumer may get from the shopping activities (Mohan et al., 2013). Consumers' positive emotions entail excitement, enjoyment, relaxation, and inspiration (Verhagen \& van Dolen, 2011). With a growing sense of pleasure when using online platforms, the possibility of the consumer making an impulse buying decision increases. Therefore, in developing ecommerce support systems, a tacit understanding of the factors influencing customer enjoyment is necessary to stimulate impulse purchasing behavior (Do et al., 2020). Sohn and Lee (2017) posited that consumers' emotional experience impacted their impulse buying decisions positively. Hasima et al. (2020) found from the study that perceived enjoyment did mediate the relationship between online store environment, promotions, and impulse purchase and had a direct positive and significant association with an online impulse purchase. Baskaran et al. (2019) examined impulse buying behavior and found that impulse purchases among wen are genuinely based on the stimulation effects of perceived enjoyment. Xiang et al. (2016) studied perceived enjoyment as a mediator to examine impulse buying urge from e-commerce sites, and results indicated the positive relationship between enjoyment and online impulse buying. A prior study found the mediating relationship between perceived enjoyment and online impulse buying (Floh \& Madlberger, 2013; Saad \& Metawie, 2015). According to Ingham et al. (2015), perceived enjoyment can be obtained through visiting the websites, and the experience will enable them to perform certain actions such as online purchasing activities. Sometimes viewers from different vlogs pursue enjoyment and are satisfied with the content shown in vlogs that are insightful and influence them to decide to buy it immediately. Based on the abovementioned discussion, the following hypothesis is proposed:

H1: There is a positive and significant relationship between perceived enjoyment and impulse purchase towards e-tail stores.

\section{Website Stimulus}

The website stimulus refers to the characteristics of a website. Website stimulus explains the appeal offered to consumers by the user interface design (Maiyaki \& Mokhtar, 2016). Hence, website design efficiency is critical and should be a crucial factor in attracting customers for any online merchandise because customers obtain information 
about products and services through social media and online websites (Turkyilmaz et al., 2015). Previous research indicates that websites' esthetic presence is critical in attracting customers and inducing impulsive behavior (Wolfinbarger \& Gilly, 2003). It was also found that the store design aspect directly affects the purchasing of impulses. This involves ease of website use, visual presentation, safety, and security, etc. (Lo et al., 2016). Akram et al. (2018) have studied impulse buying behavior among Chinese online shoppers in China. The results revealed that the quality of the website is an essential aspect that influences Chinese online shoppers when impulsively purchasing online. Thus, a significant positive relationship between website quality and impulse buying online was found in the study of Akram et al. (2018). The characteristics of a website, such as visual appeal, transaction security, and navigation, are all specific signs which have a direct impact on impulse buying among consumers (Wells et al., 2011). Website quality attracts and retains new customers, and it is the quality of the website that influences consumers' preferences for a specific website (Sharma \& Lijuan, 2015). Earlier literature indicates that their many characteristics can improve the quality of websites. The quality of the website may influence consumers to attempt impulse purchase (Matharaarachchi et al., 2016). Specific website personality traits such as dynamism, enthusiasm, genuineness, sophistication, and enjoyment are positively linked to purchasing impulse activity (Rezaei et al., 2016). Consumers' impulse purchase can be determined by few attributes, such as contemplated content, variety, effortless navigating, and design of the websites, which motivates them to attempt purchasing action (Wadera \& Sharma, 2018). Consumers will enjoy browsing a website if the quality of the website meets their expectations. Xiang et al. (2016) found that visual representation of e-commerce websites positively and significantly affects consumers' emotional states thus, inducing pleasure and enjoyment. Based on the literature discussed above, the following hypothesis is formed:

H2: There is a positive and significant relationship between website stimulus and perceived enjoyment.

H3: There is a positive and significant relationship between website stimulus and impulse purchase towards e-tail stores.

\section{Marketing Stimulus}

Marketing stimulus is described as the type of product, price, promotion, and bonuses offered to attract a consumer. Price is an important factor under marketing stimulus that has widely being exercised to examine impulse buying behavior (Park et al., 
2012; Sari \& Pidada, 2020; Xu \& Huang, 2014). Price reductions are offered with a discount to encourage consumers' sudden urge to buy, and it can be an initial factor to attempt the buying behavior (Yue \& Abd Razak, 2018). When prices are lowered, consumers spend less than the original price, and the perceived price discount pleases and arouses the buyer, which is a contributing factor to their impulse buying behavior (Koschate-Fischer et al., 2012). Being able to buy a product at a discounted price, making shoppers feel more optimistic about having to take the opportunity, rather than letting it go (Sundström et al., 2013). Price discount is a significant factor in the purchase of impulses, and it is one of the most common marketing promotional strategies as it is capable of delivering positive effects, resulting in buying opportunities (Park et al., 2012; Sundström et al., 2013). More precisely, when there are sales or price promotions, buyers appear to be more impulsive (Rizwan et al., 2014). Consequently, the lower price of a good is the key determinant of impulse buying (Lim \& Yazdanifard, 2015). Sales promotions are structured as a series of various promotional resources to encourage customers to buy multiple goods or services within a limited timeframe (Lo et al., 2016). Price discounts, bonus packs, and coupons are the most growing promotional efforts of online retailers ( $\mathrm{Tu}$ et al., 2017). and it results in hedonic browsing among consumers. Park et al. (2012) studied consumer's hedonic product browsing and found that consumers feel happy and relaxed when the prices are reasonable and affordable. Based on the abovementioned literature, the following hypothesis is formed:

H4: There is a positive and significant relationship between marketing stimulus and perceived enjoyment.

H5: There is a positive and significant relationship between marketing stimulus and impulse purchase towards e-tail stores.

\section{Product Variety}

Online buyers tend to be variety-seekers because they would like to explore the wide range of selections offered on websites (Lim \& Dubinsky, 2004; Moe, 2003). According to Moe (2003), a vast number of category-level pages are likely to get hedonic browsing visits, indicating that offerings from a variety of shopping malls allow customers to browse for hedonic reasons such as diversion, pleasure, or enjoyment. Furthermore, finding a variety of products improves shopping productivity by increasing access to comparable items and allowing the better choice of products by prolonged internet browsing (Sharma et al., 2006). In terms of shopping experiences, the variety of selections offers a change in 
routine and escape from boredom, which is usually a function of exploratory searches (Blakeney et al., 2010).

According to Hawkins et al. (2007), buyers will switch brands spontaneously if they discover anything new and variations of choices, and these variations will encourage customers to quickly buy or purchase without giving it a second thought. Few researchers, such as Sharma et al. (2010), revealed that variety-seeking behavior would allow consumers to engage in impulsive buying behavior because variety-seeking is directly linked to unplanned buying. Research by (Amos et al., 2014) indicated customers choosing to buy online often depends on their variety-seeking behaviours. Based on the discussion above, the following hypothesis is proposed:

H6: There is a positive and significant relationship between product variety and impulse purchase towards e-tail stores.

H7: There is a positive and significant relationship between product variety and impulse purchase towards e-tail stores.

Figure 1 Conceptual Model: Proposed Model for this Study

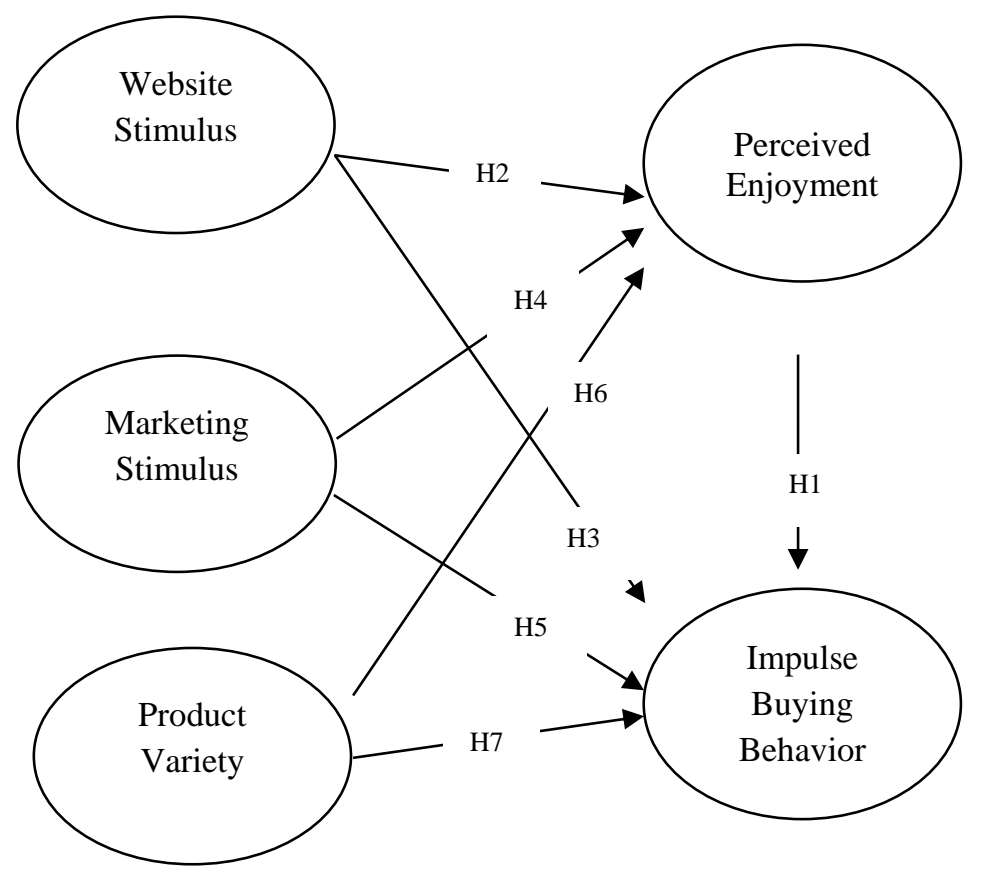




\section{METHODOLOGY}

\section{PLS-SEM (Partial Least Square Structural Equation Model)}

Social science researchers have adopted partial least squares structural equation modeling (PLS-SEM) as a standard methodology for analyzing multifaceted interrelationships between exogenous and endogenous variables (Sarstedt et al., 2020). This method provides various beneficial features which enhanced its applicability into several research sectors in the current decade (Sarstedt et al., 2020), such as the ability of handling complex models for relatively small data (Hair et al., 2017), assessing formative definite extent models (Sarstedt et al., 2016), and identify the scores for the determinate endogenous variable (Rigdom et al., 2019). According to the past published papers, PLSSEM is being emphasized for its appealing method, particularly for applied science, by promoting the testing for hypothesized relationships through a forecast emphasis in the estimation of the model (e.g., Carrión et al., 2016; Evermann \& Tate, 2016). Furthermore, PLS-SEM asphyxiates the outward contrast between explanations that generally academic research underlines and forecasts, which is necessary to develop managerial implications (Hair et al., 2019; Shmueli et al., 2016, 2019). However, several debates were acknowledged in regards to the merits and limitations of this method in different research areas (Khan et al., 2019). Hence, Hair et al. (2012) recorded 204 marketing-related studies that adopted PLS-SEM in the period of 1981-2010.

One significant implication of this method is that it provides a complementary method for robustness assessment (Latan, 2018). Researchers in regression-based studies generally check those robustness assessments to estimate the behavior of core regression coefficient when regression measurement is reformed in some way, usually with addition and confiscation regression (Lu \& White, 2014). The recent PLS-SEM guidelines include nonlinear effects, endogeneity, and unobserved heterogeneity as compulsory for any analysis (Latan, 2018). PLS-SEM is a popular methodology in recent studies relevant to consumer/users' behavior (Blasco Lopez et al., 2018; Chiang et al., 2019; Hossen et al., 2020; Marmaya et al., 2019). Therefore, this study adopted PLS-SEM to examine the influential factors on impulse buying behavior.

\section{Construct Measurement}

The deductive approach was preferred for this analysis, which concentrated on the formation of the hypotheses based on existing theory. This was followed by the appropriate research strategy which was selected to test the hypotheses (Bryman, 2008). Five constructs were assessed to test the hypotheses, including website stimulus, marketing 
stimulus, product variety, perceived enjoyment, and impulse buying behavior. However, six items of website stimulus were mainly adapted from Wells et al. (2011). Five items of the marketing stimulus were adapted from (Ali et al., 2019). Four items of product variety were adapted from Park et al. (2012). Three items of the perceived enjoyment were extracted from Sun and Zhang (2006), and for impulse purchase behavior, five items were extracted from Park et al. (2012) and then adapted for the current study. A total of twentythree items of the five variables were measured using a five-point Likert scale (e.g., $1=$ Strongly disagree to $5=$ Strongly agree) to express the degree of an agreement. Each item of the questionnaire was developed using the English language. With the aim of attaining comments and feedback from the respondents, twenty questionnaires were distributed for pilot testing $(n=20)$. The questionnaires were subsequently modified in order to bring clarity.

\section{Sample size and technique}

A sample is defined as a subgroup of the population that has been selected for participation in the research. The target respondents for this study were e-commerce users in Malaysia. However, the accessible populations for this study were the e-tail users at Klang Valley area in Malaysia. The total population was recorded at 7,996,830 based on the report of world population view 2020 (worldpopulationreview.com). The current study is aimed at getting 385 respondents based on the sample size formula shown. The study selected a non-probability sampling method which is judgment sampling, or it is also known as purposive sampling. Purposive sampling refers to a specific person who can provide information which the author needs or meets the researcher's requirements to be selected as a sample (Sekaran \& Bougie, 2010). In the current study, researchers asked the respondents through qualifying questions whether they make use of e-tailing sites or not.

$$
n=\frac{\frac{Z^{2} \times P \times(1-P)}{e^{2}}}{1+\frac{Z^{2} \times P(1-P)}{e^{2} N}} \quad n=\frac{\frac{1.96^{2} \times 0.5 \times(1-0.5)}{0.05^{2}}}{1+\frac{1.96^{2} \times 0.5(1-0.5)}{0.05^{2} 7996830}} \quad n=384
$$

\section{Data Collection}

Data for this current study were collected in a span of one month, between September and November of 2019. A total of 450 questionnaires were distributed with the aim of getting 384 for further analysis. However, only 439 responses were received from 
the respondents living at Klang Valley in Malaysia. After the data screening and cleaning processes were completed, 392 responses were unattained.

\section{ANALYSIS AND FINDINGS}

Data were analyzed using statistical software SPSS version 25.0 and PLS-SEM version 3.0. Table 1 represents the demographic profile of the participants from Klang Valley area. For this study, respondents were asked their gender, age, marital status, educational qualification, monthly income, and online buying experience.

Table 1 Demographic Profile

\begin{tabular}{clcc}
\hline Measure & \multicolumn{1}{c}{ Items } & Frequency & Percentage \\
\hline \multirow{2}{*}{ Gender } & Male & 177 & 45.15 \\
& Female & 215 & 54.85 \\
\hline \multirow{5}{*}{ Age } & $18-21$ & 40 & 10.2 \\
& $22-29$ & 196 & 50 \\
& $30-39$ & 122 & 31.12 \\
& $40-49$ & 31 & 7.91 \\
& 50 and above & 3 & 0.77 \\
\hline \multirow{5}{*}{ Marital status } & Single & 239 & 60.97 \\
& Married & 107 & 27.3 \\
& Divorced & 38 & 9.69 \\
& Widowed & 8 & 2.04 \\
\hline \multirow{5}{*}{ Educational qualification } & Diploma & 81 & 20.66 \\
& Bachelor & 189 & 48.21 \\
& Masters & 103 & 26.28 \\
& Doctorate & 19 & 4.85 \\
\hline \multirow{5}{*}{ Monthly income* } & less than RM1000 & 102 & 26.02 \\
& Between RM1000-RM1999 & 125 & 31.89 \\
& Between RM2000-RM2999 & 116 & 29.59 \\
& Between RM3000-RM3999 & 28 & 7.14 \\
& RM4000 and above & 21 & 5.36 \\
\hline \multirow{5}{*}{ Online buying experience } & Less than 1 year & 105 & 26.78 \\
& 1-2 years & 145 & 36.99 \\
& 2-3 years & 74 & 18.88 \\
& More than 3 years & 68 & 17.35 \\
\hline
\end{tabular}

Note. Malaysian Ringgit $(\mathrm{RM})=0.24$ United States Dollar (USD) 


\section{Measurement Model}

Convergent and discriminant validity tests were performed to assess the measurement model. To test convergent validity, each construct of composite reliability and Cronbach' $\alpha$ values should be higher than or equal to 0.7 (Chin, 1998). The current study shows the composite reliability (CR) values ranging from 0.897 to 0.970 and Cronbach' $\alpha$ values from 0.848 to 0.961 . The guideline for loadings is to be at least 0.5 as conferred by Hair et al. (2006). Although loading of more than 0.7 reflects more variance (Neupane et al., 2014). The loadings for each indicator are way higher than 0.7 , ranging from 0.746 to 0.954 indicates good loading. The AVE value equal to or above 0.50 implies that on average, the construct clarified more than half the variance of its indicators. By comparison, an AVE of less than 0.50 suggests that there is still more error in the items than the average variance described by the constructs. The rule of thumb therefore is that an AVE value greater than or equal to 0.50 is appropriate (Hair et al., 2013). AVE for the current study ranging from 0.685 to 0.865 . The test result of the current study may therefore infer the strong reliability of all of the items.

Discriminant validity concerns the uniqueness of a construct, whether the phenomenon captured by a construct is special and not reflected in the model by the other constructs (Hair et al., 2013). Discriminant validity can indeed be evaluated by comparing cross loads among constructs, using the Fornel-Larcker criterion and the Heterotrait-Monotrait (HTMT) correlation ratio. Discriminant validity of a construct can also be measured by comparing the square root of the AVE values with the latent variable correlations (Fornell \& Larcker, 1981). Table 2 shows the strong discriminant validity as it shows that each factor's square AVE is greater than all of its correlations with the other factors.

$$
\begin{aligned}
& * A V E=\frac{\sum \lambda_{i}^{2}}{\sum \lambda_{i}^{2}+\sum_{i} \operatorname{Var}\left(\varepsilon_{i}\right)} \\
& * C R=\frac{\left(\sum \lambda_{i}\right)^{2}}{\left(\sum \lambda_{i}\right)^{2}+\sum_{i} \operatorname{Var}\left(\varepsilon_{i}\right)}
\end{aligned}
$$


Table 2 Convergent Validity and Reliability

\begin{tabular}{lcccccccc}
\hline & AVE & CR & $\boldsymbol{\alpha}$ & OIPB & PE & PP & VS & WS \\
\hline OIPB & 0.865 & 0.970 & 0.961 & 0.930 & & & & \\
PE & 0.809 & 0.927 & 0.882 & 0.595 & 0.900 & & & \\
MS & 0.765 & 0.942 & 0.923 & 0.432 & 0.403 & 0.874 & & \\
PV & 0.685 & 0.897 & 0.848 & 0.435 & 0.410 & 0.146 & 0.828 & \\
WS & 0.742 & 0.945 & 0.931 & 0.329 & 0.354 & 0.268 & 0.202 & 0.862 \\
\hline
\end{tabular}

Note. $\mathrm{AVE}=$ Average variance extracted, $\mathrm{CR}=$ Composite reliability

\section{Structural Model}

We use the bootstrap re-sampling technique (5000 re-sample) and then test the pathcoefficient to investigate the significance of the hypotheses. The t-value> 1.96 is significant at $p<0.05$ and $t$-value $>2.58$ is significant at $p<0.01$ (Hair et al., 2017).

Figure 2 represents the PLS structural equation modeling technique. The model fit was adequate based on SRMR and Chi-Square values (Table 3). Only NFI value was below the standard threshold level. The hypothesized path coefficients are presented in Table 4.

Figure 2 and Table 3 describe the path coefficient $(\beta), t$-statistics, and $p$-value of each hypothesis. According to the findings in Table 4, all proposed hypotheses were supported except $H 3$, which indicates a direct relationship. $H 1 \quad(\beta=0.380, \mathrm{t}=2.717)$ indicates the path between perceived enjoyment of using e-tailing sites (WS) and impulse buying behavior (OIBB), describing an existence of a significant positive relationship in between. $H 2(\beta=0.208, \mathrm{t}=2.701)$ shows the path between website stimulus and online impulse buying behavior, which shows a significant positive relationship between WS of e-tailing stores and OPBB. $H 3(\beta=0.089, \mathrm{t}=0.785)$ describes that website stimulus (WS) has no positive and significant influence on OIBB. $H 4(\beta=0.300, t=3.168)$ ascertains the direct, positive, and significant relationship between marketing stimulus (MS) and perceived enjoyment (PE). $H 5(\beta=0.221, \mathrm{t}=1.982)$ indicates the relationship between marketing stimulus (MS) from online commerce sites and OIBB, which were found to have positive and significant thus, supported for the current study. $H 6(\beta=0.324, \mathrm{t}=4.022)$ alludes that there was a significant positive association between product variety (PV) and online impulse buying behavior (OIBB). Lastly, $H 7(\beta=0.229, \mathrm{t}=2.260)$ was found to be significant where it shows a positive association between product variety and online impulse buying behavior. 
Figure 2 PLS-SEM Structured Model

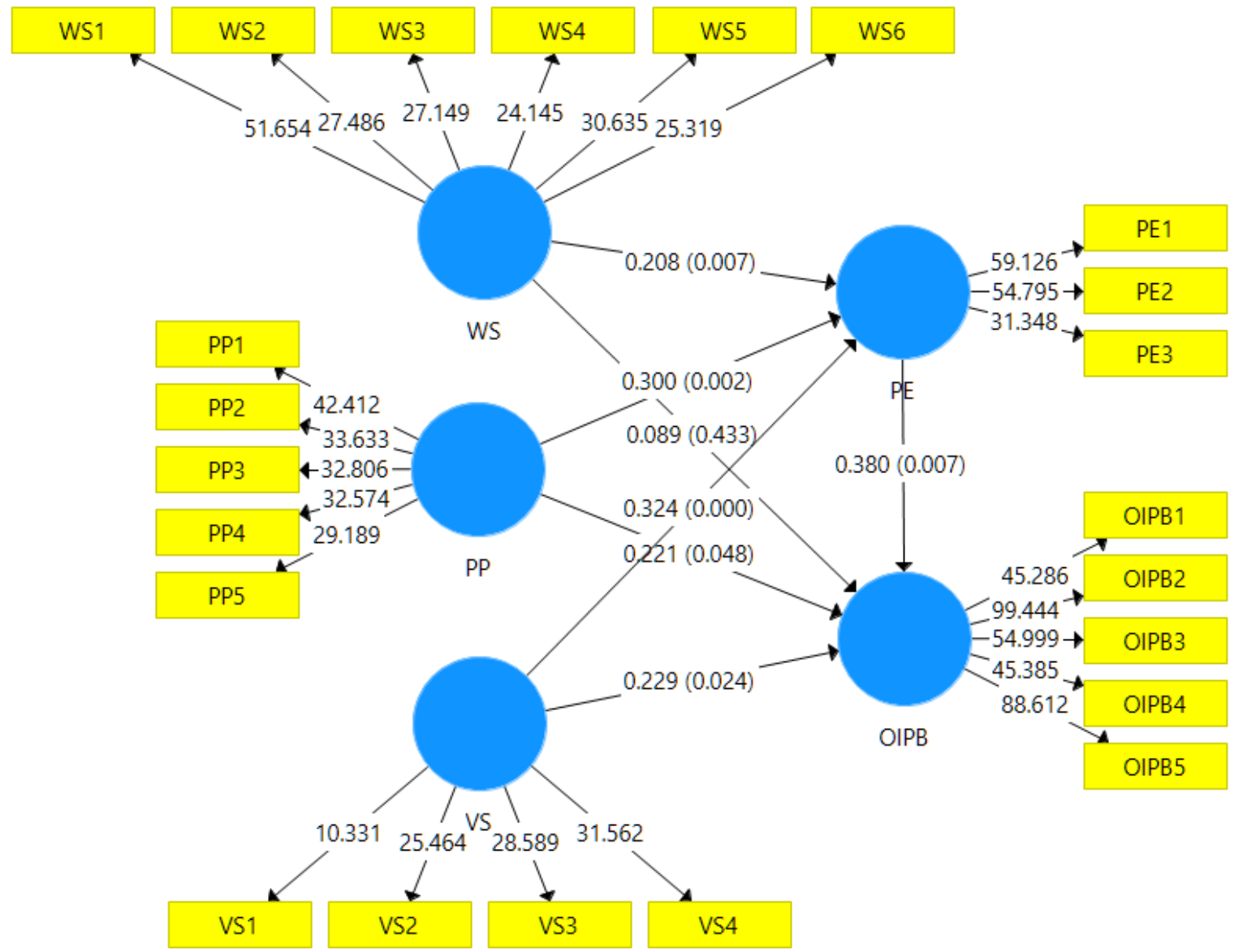

Table 3 Model Fit

\begin{tabular}{lcc}
\hline Fit Indices & Estimated Model & Ideal Threshold \\
\hline SRMR & 0.043 & $<0.08$ \\
Chi-Square & 539.489 & Upper is Better \\
NFI & 0.877 & $>0.9$ \\
\hline
\end{tabular}


Table 4 Hypothesis Testing

\begin{tabular}{clcccc}
\hline Hypothesis & Relationship & $\boldsymbol{\beta}$ & t-stats & p-value & Decision \\
\hline $\mathrm{H} 1$ & $\mathrm{PE} \rightarrow \mathrm{OIBB}$ & 0.380 & 2.717 & $* *$ & Supported \\
$\mathrm{H} 2$ & $\mathrm{WS} \rightarrow \mathrm{PE}$ & 0.208 & 2.701 & $* *$ & Supported \\
$\mathrm{H} 3$ & $\mathrm{WS} \rightarrow \mathrm{OIBB}$ & 0.089 & 0.785 & 0.433 & Not Supported \\
$\mathrm{H} 4$ & $\mathrm{MS} \rightarrow \mathrm{PE}$ & 0.300 & 3.168 & $* *$ & Supported \\
$\mathrm{H} 5$ & $\mathrm{MS} \rightarrow \mathrm{OIBB}$ & 0.221 & 1.982 & $*$ & Supported \\
$\mathrm{H} 6$ & $\mathrm{PV} \rightarrow \mathrm{PE}$ & 0.324 & 4.022 & $* * *$ & Supported \\
$\mathrm{H} 7$ & $\mathrm{PV} \rightarrow \mathrm{OIBB}$ & 0.229 & 2.260 & $*$ & Supported \\
\hline
\end{tabular}

Note. ${ }^{*} \mathrm{p}<0.05 ; * * \mathrm{p}<0.01 ; * * * \mathrm{p}<0.001$

In PLS analysis, the prediction power of a specific construct to determine the standard path coefficient for each relationship between exogenous and endogenous variables is evaluated using the endogenous variables' $R$-squared $\left(R^{2}\right)$ values. The values of $R^{2}$ in PLS are interpreted similarly to those obtained from multiple regression analysis. $\mathrm{R}^{2}$ values of $0.75,0.50$, and 0.25 define substantial, moderate, and weak levels to predict the accuracy, according to Hair et al. (2014). The degree of $\mathrm{R}^{2}$ (determination coefficient) is evaluated subsequently. Website stimulus (WS), marketing stimulus (MS), and product variety (PV) accounted for $32.7 \%\left(\mathrm{R}^{2}=0.327\right)$ of variance in explaining perceived enjoyment. Meanwhile, perceived enjoyment along with WS, MS, and PV accounted for $45 \%\left(\mathrm{R}^{2}=\right.$ 0.450) of the variance in impulse buying behavior.

\section{DISCUSSION}

This study was conducted to investigate the key factors of impulse buying behavior. Factors such as website stimulus, price and promotion, and varieties of selection were examined to establish the relationship with impulse buying behavior. However, perceived enjoyment was employed to see the mediating effects between independent and dependent variables. Firstly, perceived enjoyment was found to have a significant influence on online impulse buying behavior (H1 was supported). In this study, respondents perceive that getting pleasure triggers them to indulge in spontaneous buying behavior. A prior study by Baskaran et al. (2019) found that perceived enjoyment plays a significant role in buying intention. Secondly, a positive and significant relationship is associated between website stimulus (WS) and perceived enjoyment (H2 was supported), but a negative relationship was found between WS and OIBB (H3 was rejected). Results indicate that website stimulus 
has no direct impact on impulse buying behavior, but previous studies asserted that the visual appeal of a website is pleasing among e-commerce consumers. Although impulse purchase is widely made online, Malaysians are still prudent and cautious when selecting websites for purchasing products because of fraud issues. Adopting web-based purchasing is increasing, and only a few of the customers who have successfully placed an online order did not receive all their ordered items.

Another reason worthy of highlighting is the fact that the visually attractive product that the customer paid for online was different from the one that was eventually delivered to them (Katrina \& Benedict, 2019). Visual appeal in pictures, graphics, and motions was the key determinant of a consumer's instant gratification. Thus, $\mathrm{H} 2$ was in line with the previous study of Liu et al. (2013) and Hasima et al. (2020). Thirdly, the current study's marketing stimulus was significant in determining perceived enjoyment and impulse purchase behavior towards e-tailing sites (H4 and H5 were supported); thus, the findings of this study are consistent with the prior literature of Yue and Abd Razak (2018). Lastly, both perceived enjoyment and online impulse buying were influenced by a variety of selections (H6 and H7 were supported). Bringing more varieties in the products stimulates online shoppers' emotional state; therefore, consumers urge to buy impulsively.

Table 5 Mediation Effects Analysis

Bootstrapping 95\% confidence

\begin{tabular}{ccccc} 
Relationship & Coefficient & $\mathrm{p}$ & \multicolumn{2}{c}{ intervals } \\
\cline { 4 - 5 } & & & Lower & Upper \\
\hline $\mathrm{MS} \rightarrow \mathrm{PE} \rightarrow$ OIBB & 0.114 & $*$ & 0.013 & 0.226 \\
$\mathrm{PV} \rightarrow \mathrm{PE} \rightarrow \mathrm{OIBB}$ & 0.123 & $*$ & 0.02 & 0.218 \\
$\mathrm{WS} \rightarrow \mathrm{PE} \rightarrow \mathrm{OIBB}$ & 0.079 & $*$ & 0.01 & 0.145 \\
\hline
\end{tabular}

Note. ${ }^{*} \mathrm{p}<0.05 ;{ }^{* *} \mathrm{p}<0.01 ; * * * \mathrm{p}<0.001$ ( $\mathrm{p}$ value)

Three mediating effects in this study were examined. Firstly, the study examined the mediating effect of perceived enjoyment on the relationship between marketing stimulus and online impulse buying behavior. Then the study investigates perceived enjoyment on the relationship between product variety and online impulse buying behavior and, finally, perceived enjoyment on the relationship between website stimulus and OIBB. With 95\% confidence intervals, 5000 simulations were bootstrapped and found no 0 straddle in between (Efron \& Tibshirani, 1993). The study indicates that perceived enjoyment has 
significant and positive impacts on website stimulus, price and promotion and online impulse purchase behavior.

\section{Implications}

The findings can be important for both practical and theoretical implications on consumers' impulse buying behavior. At the practical level, the transition from consumers' planned purchase to impulse buying behavior influenced by marketing stimulus and product varieties provides an important direction to the retailers. Therefore, these findings can be useful to retailers and companies to design their strategies for attracting customers. Retailers and marketers should acknowledge during the development of their strategies that Malaysian consumers are concern over market stimulus and product varieties. Further, retailers and companies should keep their websites vibrant and update from time to time with accurate information. Theoretically, the findings may enhance the understanding of individuals' differences in impulse buying behavior, thus expanding knowledge related to the relationships among antecedents and impulse buying behavior patterns.

\section{Limitation and Future Research Direction}

This research has its limitations. Firstly, due to the time constraints, the data were collected through online platforms and social media, and respondents were mainly from Klang Valley area. Thus, the study should be inclusive of the entire Malaysia, including Sabah and Sarawak areas, respectively. Secondly, due to the movement control order (MCO) imposed in Malaysia to curb the spread of COVID-19, face-to-face questionnaire distribution was interrupted, and alternative data collection was carried out online and via social media. Therefore, a high possibility of getting false and unexpected answers was a remaining spectacle. Thus, it is recommended that the study should be conducted through the physical distribution of research questionnaires. Though website stimulus had widely being exercised in the impulsive purchase studies, especially in terms of online or ecommerce purchase, variety of selection was comparatively less concentrated in the area of impulse buying online, and few more factors are to be applied in order to study impulsive purchase via e-retailing stores.

However, it is further recommended that future studies should be carried out in the entire country (Malaysia), including rural and urban areas. Therefore, the study should also focus on employed citizens or salaried workers because the impulse purchase behavior may vary based on situational factors such as time and availability of money. Similarly, the study would focus on the buying behavior between genders. However, further study could 
apply different factors such as e-service quality, reliability, and e-trust to investigate eimpulsive buying behavior.

\section{REFERENCE}

Ahmad, M. B., Ali, H. F., Malik, M. S., Humayun, A. A., \& Ahmad, S. (2019). Factors affecting impulsive buying behavior with mediating role of positive mood: An empirical study. European Online Journal of Natural and Social Sciences, 8(1), 1735 .

Akram, U., Hui, P., Khan, M. K., Tanveer, Y., Mehmood, K., \& Ahmad, W. (2018). How website quality affects online impulse buying. Asia Pacific Journal of Marketing and Logistics, 30(1), 235-256.

Ali, S. S., Aziz, Y. A., Yusuf, R. R., \& Imm, N. S. (2019). Evaluation the role of sales promotion in influencing impulse buying behavior: A Comparison between international and local tourist at premium outlet in Malaysia. Journal of Tourism, 4(15), 32-43. https://doi.org/10.35631/jthem.415004

Al-Salamin, H., \& Al-Hassan, E. (2016). The impact of pricing on consumer buying behavior in Saudi Arabia: Al-Hassa case study. European Journal of Business and management, 8(12), 62-73.

Amos, C., Holmes, G. R., \& Keneson, W. C. (2014). A meta-analysis of consumer impulse buying. Journal of Retailing and Consumer Services, 21(2), 86-97. https://doi.org/10.1016/j.jretconser.2013.11.004

Aragoncillo, L., \& Orus, C. (2018). Impulse buying behaviour: an online-offline comparative and the impact of social media. Spanish Journal of Marketing-ESIC, 22(1), 42-62.

Arbaina, S., \& Suresh, A. S. (2018). Factors influencing consumer's purchase intention on social networking sites: Evidence from Bangalore. Ushus-Journal of Business Management, 17(4), 41-58. https://doi.org/10.12725/ujbm.45.3

Baskaran, S., Yuen, T. M., Mahmood, Z., Mahadi, N., \& Dalayga, B. (2019). Do women buy online impulsively more often out of enjoyment and risk tolerance? International Journal of Academic Research in Business and Social Sciences, 9(7), 88-107. https://doi.org/10.6007/ijarbss/v9-i7/6094

Beatty, S. E., \& Ferrell, M. E. (1998). Impulse buying: Modeling its precursors. Journal of retailing, 74(2), 169-191. https://doi.org/10.1016/s0022-4359(99)80092-X 
Bemmaor, A. C. (1984). Testing alternative econometric models on the existence of advertising threshold effect 298. Journal of Marketing Research, 21(3), 298. https://doi.org/10.2307/3151606

Bharathi, K., \& Sudha, S. (2017). Store ambiance influence on consumer impulsive buying behavior towards apparel: SOR model. Indian Journal of Public Health Research \& Development, 8(4), 140-144. https://doi.org/10.5958/0976$\underline{5506.2017 .00329 .1}$

Bhuvaneswari, K. J., \& Krishnan, J. (2015). A review of literature on impulse buying behaviour of consumers in brick \& mortar and click only stores. International Journal of Management Research and Social Science (Ijmrss), 2(3), 84-90.

Blakeney, A., Findley, C., Self, D. R., Ingram, R., \& Garrett, T. (2010). Media habits of sensation seekers. Journal of Global Academy of Marketing Science, 20(2), 179-187. https://doi.org/10.1080/12297119.2010.9730190

Blasco Lopez, M., Recuero Virto, N., \& San-Martin, S. (2018). Local food shopping: Factors affecting users' behavioural e-loyalty. Administrative Sciences, 8(3), 47. https://doi.org/10.3390/admsci8030047

Bryman, A. (2008). Social research methods. Oxford: Oxford University Press.

Buckley, P. G. (1991). An SOR model of the purchase of an item in a store. Advances in Consumer Research, 18(1), 491-500.

Carrión, G. C., Henseler, J., Ringle, C. M., \& Roldán, J. L. (2016). Prediction-oriented modeling in business research by means of PLS path modeling: Introduction to a JBR special section. Journal of Business Research, 69(10), 4545-4551. https://doi.org/10.1016/j.jbusres.2016.03.048

Chevalier, M. (1975). Increase in sales due to in-store display. Journal of Marketing Research, 12(4), 426-431. https://doi.org/10.1177/002224377501200406

Chiang, I. P., Lin, K. C., Huang, C. H., \& Yang, W. L. (2019). Influence factors of people purchasing on social commerce sites. Contemporary Management Research, 15(2), 69-87. https://doi.org/10.7903/cmr.18575

Chin, W. W. (1998). The partial least squares approach to structural equation modeling. Modern methods for business research, 295(2), 295-336.

Choudhary, S. (2014). Study of impulse buying behavior of consumers. International Journal of Advance Research in Computer Science and Management Studies, 2(9), $1-4$. 
Do, H. N., Shih, W., \& Ha, Q. A. (2020). Effects of mobile augmented reality apps on impulse buying behavior: An investigation in the tourism field. Heliyon, 6(8), e04667. https://doi.org/10.1016/j.heliyon.2020.e04667

Donovan, R., \& Rossiter, J. (1982). Store atmosphere: An environmental psychology approach. Journal of Retailing, 58(1), 34-57.

Efron, B., \& Tibshirani, R. J. (1993). An introduction to the bootstrap. Chapman and Hall: London, UK, 1993.

Engel, J. F., \& Blackwell, R. D. (1982). Consumer behavior. Dryden press.

Eroglu, S. A., Machleit, K. A., \& Davis, L. M. (2001). Atmospheric qualities of online retailing: A conceptual model and implications. Journal of Business Research, 54(2), 177-184. https://doi.org/10.1016/s0148-2963(99)00087-9

Evermann, J., \& Tate, M. (2016). Assessing the predictive performance of structural equation model estimators. Journal of Business Research, 69(10), 4565-4582. https://doi.org/10.1016/j.jbusres.2016.03.050

Floh, A., \& Madlberger, M. (2013). The role of atmospheric cues in online impulsebuying behavior. Electronic Commerce Research and Applications, 12(6), 425-439. https://doi.org/10.1016/j.elerap.2013.06.001

Fornell, C., \& Larcker, D. F. (1981). Evaluating structural equation models with unobservable variables and measurement error. Journal of Marketing Research, 18(1), 39-50. https://doi.org/10.1177/002224378101800104

Graa, A., \& Dani, E. (2012). Application of stimulus \& response model to impulse buying behavior of Algerian consumers. Serbian Journal of Management, 7(1), 5364. https://doi.org/10.5937/sjm1201053g

Hair, J. F., Hult, G. M., Ringle, C., \& Sarstedt, M. (2014). A primer on partial least squares structural equation modeling (PLS-SEM) (1st ed.). Thousand Oaks, CA: Sage.

Hair, J. F., Ringle, C. M., \& Sarstedt, M. (2013). Partial least squares structural equation modeling: Rigorous applications, better results and higher acceptance. Long Range Planning, 46(1-2), 1-12. https://doi.org/10.1016/j.lrp.2013.01.001

Hair, J. F., William, B. C., Barry, B. J., Rolph, A. E., \& Ronald, T. L. (2006). Multivariate Data Analysis (Sixth ed.). New Jersey: Pearson Education, Inc.

Hair, J., Hult, G. M., Ringle, C. M., Sarstedt, M., \& Thiele, K. O. (2017). Mirror, mirror on the wall: A comparative evaluation of composite-based structural equation modeling methods. Journal of the Academy of Marketing Science, 45(5), 616-632. https://doi.org/10.1007/s11747-017-0517-x 
Hair, J., Risher, J. J., Sarstedt, M., \& Ringle, C. M. (2019). When to use and how to report the results of PLS-SEM. European Business Review, 31(1), 2-24. https://doi.org/10.1108/ebr-11-2018-0203

Hair, J., Sarstedt, M., Ringle, C. M., \& Mena, J. A. (2012). An assessment of the use of partial least squares structural equation modeling in marketing research. Journal of the Academy of Marketing Science, 40(3), 414-433. https://doi.org/10.1007/s11747$\underline{011-0261-6}$

Hasanov, J., \& Khalid, H. (2015). The impact of website quality on online purchase intention of organic food in Malaysia: A WebQual model approach. Procedia Computer Science, 72(6), 382-389. https://doi.org/10.1016/j.procs.2015.12.153

Hashmi, H., Attiq, S., \& Rasheed, F. (2019). Factors affecting online impulsive buying behavior: A stimulus organism response model approach. Market Forces, 14(1), 1942.

Hasima, M. A., Hassanb, S., Ishakc, M. F., \& Abd Razakd, A. (2020). Factors influencing Gen-Y in Malaysia to purchase impulsively: A mediating effect of perceived enjoyment. International Journal of Innovation, Creativity and Change, 11(5), 385-396.

Hausman, A. (2000). A multi-method investigation of consumer motivations in impulse buying behavior. Journal of Consumer Marketing, 17(5), 403-426. https://doi.org/10.1108/07363760010341045

Hawkins, D. I., Roger, I. J., Coney, K. A., \& Mookerjee, A. (2007). Consumer Behavior. New Delhi: McGraw Hill.

Hetharie, J. A., Hussein, A. S., \& Puspaningrum, A. (2019). SOR (Stimulus-organismresponse) model application in observing the influence of impulsive buying on consumer"s post-purchase regret. International Journal of Scientific and Technology Research, 8(11), 2829-2841.

Hossen, M. M., Chan, T. J., \& Mohd Hasan, N. A. (2020). Mediating role of job satisfaction on internal corporate social responsibility practices and employee engagement in higher education sector. Contemporary Management Research, 16(3), 207-227. https://doi.org/10.7903/cmr.20334

Ingham, J., Cadieux, J., \& Berrada, A. M. (2015). E-Shopping acceptance: A qualitative and meta-analytic review. Information \& Management, 52(1), 44-60. https://doi.org/10.1016/j.im.2014.10.002 
Jones, M. A., Reynolds, K. E., Weun, S., \& Beatty, S. E. (2003). The product-specific nature of impulse buying tendency. Journal of Business Research, 56(7), 505-511. https://doi.org/10.1016/s0148-2963(01)00250-8

Karbasivar, A., \& Yarahmadi, H. (2011). Evaluating effective factors on consumer impulse buying behavior. Asian Journal of Business Management Studies, 2(4), 174181.

Katrina, B., \& Benedict, L. (2019, April 18). Why are Malaysians shopping online? Janio Asia. https://janio.asia/articles/why-are-malaysians-shopping-online/

Khan, G. F., Sarstedt, M., Shiau, W. L., Hair, J. F., Ringle, C. M., \& Fritze, M. P. (2019). Methodological research on partial least squares structural equation modeling (PLSSEM): An analysis based on social network approaches. Internet Research, 29(3), 407-429. https://doi.org/10.1108/intr-12-2017-0509

Koschate-Fischer, N., Diamantopoulos, A., \& Oldenkotte, K. (2012). Are consumers really willing to pay more for a favorable country image? A study of country-oforigin effects on willingness to pay. Journal of International Marketing, 20(1), 1941. https://doi.org/10.1509/jim.10.0140

Latan, H. (2018). PLS path modeling in hospitality and tourism research: The golden age and days of future past. In F. A. Cihan Cobanoglu, \& S. Mostafa Rasoolimanesh (Eds.), Applying partial least squares in tourism and hospitality research (1st ed., pp. 53-83): Emerald Publishing Limited.

Lee, T. S., Md Ariff, M. S., Zakuan, N., \& Sulaiman, Z. (2016). Assessing website quality affecting online purchase intention of Malaysia'S young consumers. Advanced Science, Engineering and Medicine, 8(10), 836-840. https://doi.org/10.1166/asem.2016.1937

Li, Y. (2015). Impact of impulsive buying behavior on postimpulsive buying satisfaction. Social Behavior and Personality: An International Journal, 43(2), 339-351. https://doi.org/10.2224/sbp.2015.43.2.339

Liao, C., To, P. L., Wong, Y. C., Palvia, P., \& Kakhki, M. D. (2016). The impact of presentation mode and product type on online impulse buying decisions. Journal of Electronic Commerce Research, 17(2), 153-168.

Lim, H., \& Dubinsky, A. J. (2004). Consumers' perceptions of e-shopping characteristics: An expectancy-value approach. Journal of Services Marketing, 18(7), 500-513. https://doi.org/10.1108/08876040410561839 
Lim, P. L., \& Yazdanifard, R. (2015). What internal and external factors influence impulsive buying behavior in online shopping? Global Journal of Management and Business Research, 15(5), 25-32.

Liu, Y., Li, H., \& Hu, F. (2013). Website attributes in urging online impulse purchase: An empirical investigation on consumer perceptions. Decision Support Systems, 55(3), 829-837. https://doi.org/10.1016/j.dss.2013.04.001

Lo, L. S., Lin, S. W., \& Hsu, L. Y. (2016). Motivation for online impulse buying: A twofactor theory perspective. International Journal of Information Management, 36(5), 759-772. https://doi.org/10.1016/j.ijinfomgt.2016.04.012

Lu, K. H., \& Wu, C. M. (2019). Moderating effects of shopping values on the antecedents of unplanned purchase behavior: An empirical study of an international travel fair. Contemporary Management Research, 15(2), 123-145. https://doi.org/10.7903/cmr.19136

Lu, X., \& White, H. (2014). Robustness checks and robustness tests in applied economics. Journal of Econometrics, 178(PART 1), 194-206. https://doi.org/10.1016/j.jeconom.2013.08.016

Maiyaki, A. A., \& Mokhtar, S. S. (2016). Correlates of consumer online buying behavior. International Journal of Management and Applied Science, 2(1), 12-18.

Marmaya, N. H., Zakaria, Z., \& Mohd Desa, M. N. (2019). Gen Y consumers' intention to purchase halal food in Malaysia: A PLS-SEM approach. Journal of Islamic Marketing, 10(3), 1003-1014. https://doi.org/10.1108/jima-08-2018-0136

Matharaarachchi, R., Abeysekera, N., \& Nawala, N. (2016). Factors influencing on online impulse buying. Young Economists Journal/Revista Tinerilor Economisti, 13(27), 127-140.

Mehrabian, A., \& Russell, J. A. (1974). An approach to environmental psychology. the MIT Press.

Moe, W. W. (2003). Buying, searching, or browsing: Differentiating between online shoppers using in-store navigational clickstream. Journal of consumer psychology, 13(1-2), 29-39. https://doi.org/10.1207/153276603768344762

Mohan, G., Sivakumaran, B., \& Sharma, P. (2013). Impact of store environment on impulse buying behavior. European Journal of Marketing, 47(10), 1711-1732. https://doi.org/10.1108/ejm-03-2011-0110

Monroe, K. B., \& Bitta, A. J. (1978). Models for Pricing Decisions. Journal of Marketing Research, 15(3), 413. https://doi.org/10.2307/3150590 
Muruganantham, G., \& Bhakat, R. (2013). A Review of Impulse Buying Behavior. International Journal of Marketing Studies, 5(2), 149-160. doi:10.5539/ijms.v5n3p149

Mwencha, P. M., Muathe, S. M., \& Thuo, J. K. (2014). Effects of perceived attributes, perceived risk and perceived value on usage of online retailing services. Journal of Management Research, 6(2), 140-161. https://doi.org/10.5296/jmr.v6i2.5224

Neupane, R. (2014). Relationship between customer satisfaction and business performance in lloyds bank uk: A case study. International Journal of Social Sciences and Management, 1(2), 74-85. doi:10.3126/ijssm.v1i2.10019

Park, E. J., Kim, E. Y., Funches, V. M., \& Foxx, W. (2012). Apparel product attributes, web browsing, and e-impulse buying on shopping websites. Journal of Business Research, 65(11), 1583-1589. https://doi.org/10.1016/j.jbusres.2011.02.043

Peng, C., \& Kim, Y. G. (2014). Application of the stimuli-organism-response (SOR) framework to online shopping behavior. Journal of Internet Commerce, 13(3-4), 159-176. https://doi.org/10.1080/15332861.2014.944437

Piron, F. (1991). Defining impulse purchasing. Advances in Consumer Research, 18, 509514.

Rezaei, S., Ali, F., Amin, M., \& Jayashree, S. (2016). Online impulse buying of tourism products. Journal of Hospitality and Tourism Technology, 7(1), 60-83. https://doi.org/10.1108/jhtt-03-2015-0018

Rigdom, E., Becker, J. M., \& Sarstedt, M. (2019). Factor indeterminacy as metrological uncertainty: Implications for advancing psychological measurement. Multivariate Behavioral Research, 54(3), 429-443. https://doi.org/10.1080/00273171.2018.1535420

Rizwan, M., Umair, M. A., Fiaz, A., \& Rashid, Q. (2014). Determinants of Customer Satisfaction and its impact on Customer loyalty in Nokia brand. Journal of Sociological Research, 5(1), 430-448. https://doi.org/10.5296/jsr.v5i1.6574

Rook, D. W., \& Fisher, R. J. (1995). Normative influences on impulsive buying behavior. Journal of Consumer Research, 22(3), 305-313. https://doi.org/10.1086/209452 Saad, M., \& Metawie, M. (2015). Store Environment, Personality Factors and Impulse Buying Behavior in Egypt: The Mediating Roles of Shop Enjoyment and Impulse Buying Tendencies. Journal of Business and Management Sciences, 3(2), 69-77. doi:10.12691/jbms-3-2-3

Sari, D. F., \& Pidada, I. I. (2020). Hedonic shopping motivation, shopping lifestyle, price reduction toward impulse buying behavior in shopping center. International Journal 
of Business, Economics \& Management, 3(1), 48-54.

https://doi.org/10.31295/ijbem.v3n1.114

Sarstedt, M., Hair, J. F., Ringle, C. M., Thiele, K. O., \& Gudergan, S. P. (2016).

Estimation issues with PLS and CBSEM: Where the bias lies! . Journal of Business

Research, 69(10), 3998-4010. https://doi.org/10.1016/j.jbusres.2016.06.007

Sarstedt, M., Ringle, C. M., Cheah, J. H., Ting, H., Moisescu, O. I., \& Radomir, L. (2020). Structural model robustness checks in PLS-SEM. Tourism Economics, 26(4), 531-554. https://doi.org/10.1177/1354816618823921

Sekaran, U., \& Bougie, R. (2010). Research methods for business: A skill-building approach (5th ed.). Chichester: Wiley.

Sharma, G., \& Lijuan, W. (2015). The effects of online service quality of e-commerce Websites on user satisfaction. The Electronic Library, 33(3), 468-485.

https://doi.org/10.1108/el-10-2013-0193

Sharma, P., Bharadhwaj, S., \& Roger, M. (2010). Impulse buying and variety seeking: A trait-correlates perspective. Journal of Business Research, 63(3), 276-283. doi:10.1016/j.jbusres.2009.03.013

Sharma, P., Sivakumaran, B., \& Marshall, R. (2006). Investigating impulse buying and variety seeking: Toward a general theory of hedonic purchase behaviors. Advances in Consumer Research, 33(1), 388-389.

Shen, K. N., \& Khalifa, M. (2012). System design effects on online impulse buying. Internet Research, 22(4), 396-425. https://doi.org/10.1108/10662241211250962

Shmueli, G., Ray, S., Velasquez Estrada, J. M., \& Chatla, S. B. (2016). The elephant in the room: Predictive performance of PLS models. Journal of Business Research, 69(10), 4552-4564. https://doi.org/10.1016/j.jbusres.2016.03.049

Shmueli, G., Sarstedt, M., Hair, J. F., Cheah, J. H., Ting, H., Vaithilingam, S., \& Ringle, C. M. (2019). Predictive model assessment in PLS-SEM: Guidelines for using PLSpredict. European Journal of Marketing, 53(11), 2322-2347.

https://doi.org/10.1108/ejm-02-2019-0189

Sohn, H. K., \& Lee, T. J. (2017). Tourists' impulse buying behavior at duty-free shops: the moderating effects of time pressure and shopping involvement. Journal of Travel and Tourism Marketing, 34(3), 341-356. https://doi.org/10.1080/10548408.2016.1170650

Stern, H. (1962). The significance of impulse buying today. Journal of Marketing, 26(2), 59-62. https://doi.org/10.1177/002224296202600212 
Sultan, S., Jan, F. A., Basit, A., \& Rafiq, A. (2018). Impact of environmental factors on impulse buying: Mediating role of consumers positive emotions. Contemporary Issues in Business \& Economics (ICCIBE), 528-535.

Summers, T. A., \& Hebert, P. R. (2001). Shedding some light on store atmospherics: Influence of illumination on consumer behavior. Journal of Business Research, 54(2), 145-150. https://doi.org/10.1016/s0148-2963(99)00082-x

Sun, H., \& Zhang, P. (2006). Causal relationships between perceived enjoyment and perceived ease of use: An alternative approach. Journal of the Association for Information Systems, 7(1), 618-645. https://doi.org/10.17705/1jais.00100

Sundström, M., Balkow, J., Florhed, J., Tjernström, M., \& Wadenfors, P. (2013, July 35). Impulsive buying behaviour: The role of feelings when shopping for online fashion [Conference presentation]. EAERCD 2013, University of Valencia, Spain, 1-22.

Tu, C. K., Wu, K. W., Jean, C. H., \& Huang, Y. (2017). The impact of online promotions on online impulsive buying behavior: Mediating effects of perceived value and positive emotion and moderating effect of online reviews. Economics \& Management, 1(1), 280-282. https://doi.org/10.26480/icemi.01.2017.280.282

Turkyilmaz, C. A., Erdem, S., \& Uslu, A. (2015). The effects of personality traits and website quality on online impulse buying. Procedia-Social and Behavioral Sciences, 175, 98-105. https://doi.org/10.1016/j.sbspro.2015.01.1179

Verhagen, T., \& van Dolen, W. (2011). The influence of online store beliefs on consumer online impulse buying: A model and empirical application. Information \& Management, 48(8), 320-327. https://doi.org/10.1016/j.im.2011.08.001

Verplanken, B., \& Herabadi, A. (2001). Individual differences in impulse buying tendency: Feeling and no thinking. European Journal of Personality, 15(1), 71-83. https://doi.org/10.1002/per.423

Vonkeman, C., Verhagen, T., \& Van Dolen, W. (2017). Role of local presence in online impulse buying. Information \& Management, 54(8), 1038-1048. https://doi.org/10.1016/j.im.2017.02.008

Wadera, D., \& Sharma, V. (2018). Impulsive buying behavior in online fashion apparel shopping: An investigation of the influence of the internal and external factors among Indian shoppers. South Asian Journal of Management, 25(3), 55-82.

Wells, J. D., Parboteeah, V., \& Valacich, J. S. (2011). Online impulse buying: understanding the interplay between consumer impulsiveness and website quality. 
Journal of the Association for Information Systems, 12(1), 32-56.

https://doi.org/10.17705/1jais.00254

Wolfinbarger, M., \& Gilly, M. C. (2003). eTailQ: Dimensionalizing, measuring and predicting etail quality. Journal of retailing, 79(3), 183-198.

https://doi.org/10.1016/s0022-4359(03)00034-4

Wu, L., Chen, K. W., \& Chiu, M. L. (2016). Defining key drivers of online impulse purchasing: A perspective of both impulse shoppers and system users. International Journal of Information Management, 36(3), 284-296. https://doi.org/10.1016/j.ijinfomgt.2015.11.015

Xiang, L., Zheng, X., Lee, M. K., \& Zhao, D. (2016). Exploring consumers' impulse buying behavior on social commerce platform: The role of parasocial interaction. International journal of information management, 36(3), 333-347. https://doi.org/10.1016/j.ijinfomgt.2015.11.002

Xu, Y., \& Huang, J. S. (2014). Effects of price discounts and bonus packs on online impulse buying. Social Behavior and Personality: An International Journal, 42(8), 1293-1302. https://doi.org/10.2224/sbp.2014.42.8.1293

Yue, C. Y., \& Abd Razak, A. Z. (2018). Impulse buying behavior among working ladies: A literature review. International Journal of Accounting, 3(13), 26-34.

Zhao, Z., Du, X., Liang, F., \& Zhu, X. (2019). Effect of product type and time pressure on consumers' online impulse buying intention. Journal of Contemporary Marketing Science, 2(2), 137-154. https://doi.org/10.1108/JCMARS-01-2019-0012

Zhu, H., Yang, Z., Ou, C. J., Liu, H., \& Davison, R. M. (2015). Investigating the impacts of recommendation agents on impulsive purchase behaviour. ACIS 2015 Proceedings - 26th Australasian Conference on Information Systems, (pp. 1-12).

Mr. Md Wasiul Karim (Corresponding author) has completed his MBA, focusing on marketing. The primary research focuses on the factors affecting impulse purchase behavior among generation Y in Malaysia. His research interests include consumer behavior, marketing research, Islamic finance and banking, quantitative research, and digital marketing.

Dr. Mohammad Abdul Matin Chowdhury recently completed a Ph.D. in Business Administration with a major in finance. He has an MSc in finance, especially in the microfinance sector. His research interests include behavioral finance, financial planning, Islamic finance and banking, consumer behavior, and banking performance and efficiency. 
Mr. Md Abdullah Al Masud is currently pursuing his doctorate in business administration, focusing on marketing. The primary research focuses on the influence of e-marketing, e-WOM, perceived risk, and perceived usefulness through online trust on online purchase intentions. He completed his MSc in marketing while focusing on customer loyalty in the fast-food industry in Malaysia. His research interests include consumer behavior, Islamic marketing, digital branding, social media marketing, digital customer experience, brand management, relationship marketing, business environment, and corporate social responsibility.

Mr. Md Arifuzzaman is currently pursuing a Master of Business Administrative (MBA) at Graduate School of Management (GSM), International Islamic University Malaysia, focusing on finance. In addition, his primary research areas are financial derivatives, risk management, and future and option. 